\title{
KERAGAAN DAN PRODUKTIVITAS PERKEBUNAN LADA TUMPANGSARI KOPI DI LAMPUNG UTARA
}

\author{
Performance and Productivity of Black Pepper Plantation \\ Mixed Culture with Coffee in North Lampung
}

\author{
Fembriarti Erry Prasmatiwi $^{1}$ dan Rusdi Evizal ${ }^{2 *}$
}

${ }^{1}$ Jurusan Agribisnis, ${ }^{2}$ Jurusan Agroteknologi, Fakultas Pertanian, Universitas Lampung

*E-mail Korespondensi: rusdi.evizal@fp.unila.ac.id

\begin{abstract}
ABSTRAK
Kabupaten Lampung Utara merupakan penghasil utama lada hitam Lampung yang umumnya berupa pertanaman lada sistem polikultur. Penelitian ini bertujuan untuk mempelajari keragaan dan produktivitas tanaman lada yang ditumpangsarikan dengan tanaman kopi yang dilakukan petani lada di Lampung Utara. Penelitian ini menggunakan metode survei yang dilakukan di Lampung Utara dengan mengambil 2 sampel kecamatan secara purposif yaitu Kecamatan Abung Barat dan Abung Tengah. Dari masing-masing kecamatan dipilih 2 desa yang ditentukan secara purposif. Data primer dikumpulkan menggunakan metode wawancara terhadap 93 orang petani sampel yang diambil secara acak. Untuk memperdalam keragaan pertanaman maka dilakukan kunjungan dan observasi pada kebun petani. Hasil penelitian ini menyimpulkan bahwa: (1) Sebanyak 96\% petani menerapkan sistem perkebunan lada polikultur. Kebun lada polikultur memiliki populasi tanaman lada yang lebih rendah namun dengan adanya tanaman tumpangsari dapat menyebabkan efisiensi pemanfaatan lahan meningkat sampai 30\%; (2) Kebun lada polikultur dikelola secara kurang intensif yang diindikasikan oleh rendahnya dosis pupuk dan tingginya angka kematian lada yang mencapai 7-10\% tanaman per tahun; (3) Produktivitas sistem tumpangsari ini adalah lada (konversi SPH 1600 pohon/ha) mencapai 230-260 kg/ha atau berdasar populasi faktual mencapai $190-277 \mathrm{~kg} / \mathrm{ha}$, produktivitas kopi 166-221 $\mathrm{kg} / \mathrm{ha}$, dan produktivitas jengkol 24-28 kg/pohon; (4) Menurut persepsi petani kendala utama yang dirasakan oleh umumnya petani lada $(80,2 \%$ petani) adalah adanya serangan penyakit busuk pangkal batang ada, rendahnya harga lada, dan tingginya angka kematian pohon lada. Namun demikian umumnya petani $(88,9 \%$ petani) menyatakan tidak akan mengganti lada dengan tanaman lain.
\end{abstract}

Kata kunci: Jengkol, kopi, lada, pemanfaatan lahan, produktivitas, tumpangsari

\begin{abstract}
North Lampung Regency is the main producer of Lampung black pepper, which is generally in the form of a poly-culture system of pepper cultivation. This study aims to study the performance and productivity of the pepper plant which is intercropped with coffee by farmers in North Lampung. This study used a survey method and conducted in North Lampung by taking 2 samples of the sub-districts purposively, namely Abung Barat and Abung Tengah. From each district, 2 villages were selected purposively. Primary data were collected by interviewing 93 sample farmers who were randomly sampled. To deepen the performance of planting, visits and observations of farmers' fields were conducted. The results of this study concluded that: (1) $96 \%$ of farmers applied a poly-culture pepper plantation system. Intercropping pepper plantations have a lower pepper plant population but the presence of intercropping can cause land use efficiency to increase by up to 30\%;(2) The poly-culture pepper fields are managed less intensively as indicated by the low fertilizer dosage and the high mortality rate of pepper, which reaches 7-10\% of plants per year; (3) The productivity of this intercropping system is pepper yield (conversion of SPH 1600 trees / ha) reaching 230-260 kg / ha or based on factual population reaching 190-277 kg/ha, coffee yield 166-221 kg/ha, and yield of Pithecellobium jiringa 24 $-28 \mathrm{~kg} /$ tree; (4) According to farmers' perceptions, the main constraints faced by farmers $(80.2 \%$ of
\end{abstract}


farmers) were the attack of pepper foot rot disease, low prices for pepper, and high mortality of pepper trees. However, most farmers (88.9\% of farmers) said they would not replace pepper with other crops.

Keywords: Black pepper, coffee, Pithecellobium jiringa, poly-culture, yield

\section{PENDAHULUAN}

Propinsi Lampung merupakan sentra produksi lada hitam dengan luas areal pada tahun 2017 mencapai 46.193 ha dan memproduksi 15.064 ton lada hitam kering. Lada ditanam di 11 dari 15 kabupaten/kota, dengan sentra pertanaman di Lampung Utara (11.714 ha), Way Kanan (9.463 ha), Tanggamus (7.966 ha), Lampung Barat (7.725 ha) dan Lampung Timur (5.094 ha). Urutan produksi terbesar adalah Lampung Utara (3.772 ton), Lampung Barat (3.559 ton), Tanggamus (2.372 ton), Way Kanan (1.872 ton), dan Lampung Timur (1.674 ton) (BPS Propinsi Lampung, 2018).

Lada di Lampung umumnya ditanam secara tumpangsari terutama dengan tanaman kopi, kecuali di Lampung Timur dimana tanaman kopi sudah sedikit yang ditanam, lada lebih banyak ditanam secara monokultur (Asnawi et al, 2017). Budidaya lada campuran misalnya kebun campuran lada - kopi yang paling umum ditemukan di Lampung, seperti di Lampung Barat, Tanggamus, dan Way kanan. Di wilayah pegunungan seperti di Lampung Barat dimana dominan berupa kebun kopi maka tanaman lada ditanam pada pohon pelindung tanaman kopi yang sudah ada sehingga akan terbangun kebun kopi yang dicampur tanaman lada (Evizal et al. 2020). Karena curah hujan yang tinggi di pegunungan maka tanaman lada campuran ini umumnya tidak berumur panjang yaitu 3-4 kali produksi sehingga perlu dilakukan penyulaman (Evizal dan Prasmatiwi, 2019).

Praktik agronomi lada di Lampung Utara agak sedikit berbeda, yaitu umumnya berbasis budidaya lada. Pertanaman lada dimulai sejak lahan masih subur yang dibuka dari hutan, kadar bahan organik tinggi, petani bertanam lada monokultur. Selanjutnya tanaman lada semakin kurang bagus hasilnya karena kesuburan lahan yang menurun, maka mulai disisipi tanaman kopi atau tanaman lainnya, diiringi dengan semakin turunnya populasi dan hasil, tanaman lada berubah menjadi sistem multistrata yang disebut dengan agroforestry (Evizal, 2000).

Apabila petani tetap mempertahankan sistem lada monokultur, maka setelah lada umur 15-20 tahun dan tanaman lada sudah mati semua maka petani memilih membongkar kebun lada secara total, mengolah lahan, menanami tanaman semusim dan pohon tajar lada baru, kemudian menanami lagi lada secara monokultur ataupun tumpangsari dengan tanaman kopi atau mengganti dengan tanaman lain seperti karet dan kakao. Praktik rotasi tanaman jangka panjang seperti ini dilakukan petani sebagai upaya "meremajakan" kembali lahan (Evizal dan Prasmatiwi, 2020). Kebun lada yang rusak, yaitu tanaman lada sudah banyak yang mati dan penyulaman lada sudah sulit berhasil, maka petani bertanam cabe jawa pada pohon tajar yang tadinya tempat merambat tanaman lada sehingga kebun lada berganti menjadi kebun cabe jawa (Evizal, 2013a).

Faktor-faktor lingkungan dan praktik agronomi sangat mempengaruhi produktivitas lada Lampung di antaranya adalah curah hujan, intensitas sinar atau penaungan, dan kelembaban mikro (Yudianto et al., 2014). Faktor-faktor lain yang berpengaruh adalah ketersediaan bibit unggul, perubahan iklim, serangan hama dan penyakit, harga yang rendah yang dapat mendorong petani mengganti pertanaman lada menjadi pertanaman lainnya (Karmawati et al., 2020; Krishnamurthy et al., 2011). Varietas cuaca dan keadaan unsur hara dalam tanaman akan menyebabkan terjadinya fluktuasi produksi lada yang 
disebut sebagai "alternate bearing" yaitu produksi lada yang lebat akan diikuti produksi kecil (Krishnamurthy et al., 2013).

Setelah berbuah lebat, tanaman lada akan kembali berbuah lebat apabila tersedia cukup hara dalam batang, pertumbuhan vegetatif sudah mendukung, dan keadaan iklim yang mendukung pembungaan dan pembuahan maka tanaman lada akan kembali berbuah lebat. Periode tahun dimana tanaman lada kurang banyak buahnya dipahami petani Lampung sebagai musim dimana tanaman lada sedang fokus memperbaiki cabangnya. Penelitian ini bertujuan untuk mempelajari keragaan dan produktivitas tanaman lada yang ditumpangsarikan dengan tanaman kopi yang banyak dilakukan petani lada di Lampung Utara.

\section{METODE PENELITIAN}

Penelitian ini menggunakan metode survei yang dilakukan di Lampung Utara dengan mengambil 2 sampel kecamatan secara purposif yaitu umumnya tanaman lada ditumpangsarikan dengan tanaman kopi. Kedua kecamatan sampel adalah Kecamatan Abung Barat dan Abung Tengah (Gambar 1). Dari masing-masing kecamatan dipilih 2 desa yang ditentukan secara purposif. Data primer dikumpulkan menggunakan metode wawancara terhadap 93 orang petani sampel yang ditentukan secara acak. Untuk memperdalam keragaan pertanaman maka dilakukan kunjungan dan observasi pada kebun petani. Data sekunder perkebunan kopi diperoleh dari BPS Propinsi Lampung.

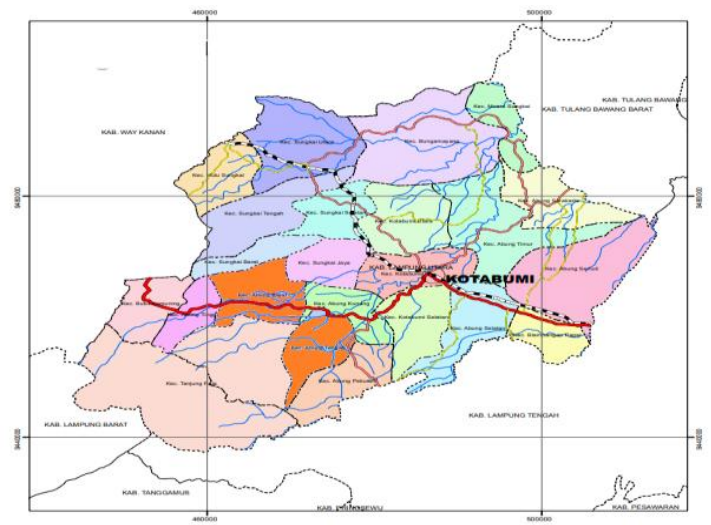

Gambar 1. Lokasi penelitian

\section{HASIL DAN PEMBAHASAN}

\section{Keragaan Pertanaman Lada}

Kebanyakan petani di kedua kecamatan (96\% petani) bertanam lada secara kebun campuran yaitu di Kecamatan Abung Barat hanya $4,3 \%$ petani yang berkebun lada monokutur dan di Kecamatan Abung Tengah hanya $3,3 \%$ petani. Petani bertanam lada menggunakan panjatan hidup yaitu pohon Gliricidia yang merupakan pohon legum yang berbintil akar, menyuburkan tanah (Evizal dan Prasmatiwi, 2005), tunasnya dimanfaatkan sebagai pakan kambing yang sangat penting pada sistem perkebunan terintegrasi (Evizal et al., 2017) dan umum digunakan sebagai pohon naungan teknis di perkebunan kopi (Evizal et al, 2016). Populasi tanaman lada berkisar 1308 1567 per hektar kebun, yang ditumpangsarikan dengan tanaman kopi dengan populasi 313-425 pohon dan tanaman jengkol dengan populasi sekitar 10 pohon/ha. Kesetaraan lahan lada tumpangsari di Abung Tengah adalah 129\% sedangkan di Abung Barat 107\% (Tabel 1).

Budidaya lada di Lampung menghadapi kendala yang berat yaitu banyaknya kematian tanaman lada akibat penyakit busuk pangkal batang lada yng disebabkan oleh jamur Phytophthora capsici, yaitu berkisar 136-153 pohon lada per ha per tahun atau sekitar 10\% dari populasi tanaman lada. Menurut persepsi petani, jumlah kematian pohon lada akibat adanya kemarau panjang berkisar 87-112 pohon atau sekitar 7\% dari tanaman. Jumlah kematian pohon lada menjadi lebih banyak apabila terjadi kemarau panjang seperti yang terjadi pada tahun 2019 dimana sekitar 222-265 tanaman mati per ha atau sekitar $17 \%$ dari populasi tanaman. Angka tersebut merupakan jumlah tanaman yang harus disulam petani setelah kebun lada mengalami kemarau panjang.

Petani lada di Abung Barat yang menyulam menggunakan stek cabang tanah sebanyak 7,9\%, menggunakan cabang gantung sebanyak $71,4 \%$, atau cabang panjat sebanyak 20,6\%. Sedangkan petani di Abung Tengah yang menyulam menggunakan stek cabang tanah sebanyak 20\%, menggunakan cabang gantung sebanyak $73,3 \%$ atau cabang panjat sebanyak $6,7 \%$ petani. Ketiga jenis bahan stek tersebut tergolong dengan cabang ortotrop yang dapat digunakan untuk memperoleh tanaman lada yang memanjat. Namun jenis bahan tanam yang 
terbaik pertumbuhannya dan tercepat merambat ke pohon panjat adalah stek dari cabang panjat (Evizal, 2013b). Petani mengaku langsung menanam stek sepanjang 6-7 ruas di kebun dan tidak melakukan pembibitan di polibag. Pembibitan lada di polibag memerlukan banyak bahan dan tenaga pemeliharaan untuk memperoleh kualitas bibit lada yang bermutu
(Munawaroh et al., 2020; Rusiva and Suherman, 2019)). Ketersediaan stek lada yang sehat di kebun sendiri untuk penyulaman sangat penting bagi petani, sehingga perlu dikembangkan agroteknologi pohon induk lada misalnya menggunakan lada sambungan dengan lada liar.

Tabel 1. Jumlah pohon tumpangsari dan kesetaraan lahan

\begin{tabular}{lllll}
\hline $\begin{array}{l}\text { Tanaman } \\
\text { tumpangsari }\end{array}$ & \multicolumn{2}{c}{ Abung Barat } & \multicolumn{2}{c}{ Abung Tengah } \\
\hline & Jml pohon/ha & $\begin{array}{l}\text { Kesetaraan luas } \\
\text { lahan (ha) }\end{array}$ & Jml pohon/ha & $\begin{array}{l}\text { Kesetaraan luas } \\
\text { lahan (ha) }\end{array}$ \\
Lada & $1308,2 \pm 251,4$ & 0,818 & $1567 \pm 213,3$ & 0,979 \\
Kopi & $313,3 \pm 55,1$ & 0,157 & $424,8 \pm 110,5$ & 0,213 \\
Jengkol & $9,4 \pm 4,8$ & 0,094 & $10,2 \pm 3,9$ & 0,102 \\
Jumlah & & 1,069 & & 1,294 \\
\hline
\end{tabular}

Keterangan: Populasi (stand per ha) lada $=1600, \mathrm{kopi}=2000$, jengkol 100 pohon/ha

Tabel 2. Kematian dan peyulaman tanaman lada

\begin{tabular}{lcc}
\hline $\begin{array}{l}\text { Kematian tanaman lada } \\
\text { Per tahun }\end{array}$ & \multicolumn{1}{c}{ Abung Barat } & Abung Tengah \\
\hline $\begin{array}{l}\text { Mati karena penyakit (pohon)(\% } \\
\text { pohon) }\end{array}$ & $136,03 \pm 37,52(10,39 \%)$ & $153,3 \pm 87,03(9,78 \%)$ \\
$\begin{array}{l}\text { Mati karena kemarau panjang } \\
\text { (pohon)(\% pohon) }\end{array}$ & $86,67 \pm 30,16(6,62 \%)$ & $111,67 \pm 69,78(7,12 \%)$ \\
$\begin{array}{l}\text { Jumlah sulaman setelah kemarau } \\
\text { (pohon)(\% pohon) }\end{array}$ & $222,70(17,02 \%)$ & $264,97(16,90 \%)$ \\
\hline
\end{tabular}

Petani lada di Lampung Utara memelihara tanaman lada secara kurang intensif, yang terlihat dari kurangnya dosis pupuk yang diberikan, bahkan di Abung Tengah sebanyak $16,7 \%$ petani mengaku sama sekali tidak memberi pupuk buatan. Di Abung Barat sebanyak 50,8\% petani dan di Abung Tengah sebanyak $43,3 \%$ petani mengaku tidak memberi pupuk urea. Di Abung Barat yang tidak memberi pupuk Phonska sebanyak $57,1 \%$, tidak memberi $\mathrm{KCl} 68,3 \%$, dan tidak memberi pupuk majemuk NPK sebanyak 57,1\% petani. Di Abung Tengah yang tidak memberi pupuk Phonska sebanyak $63,3 \%$, tidak memberi $\mathrm{KCl} 83,3 \%$, dan tidak memberi pupuk majemuk NPK sebanyak $60 \%$ petani. Kenyataan ini merupakan tantangan bagi upaya intensifikasi lada di Lampung Utara, sekaligus juga merupakan kesempatan untuk mendorong budidaya lada secara alami menuju produksi lada organik (Sulok et al., 2018).

\section{Produktivitas Lada}

Populasi tanaman lada per hektar sistem tumpangsari kopi umumnya kurang dari standar yaitu SPH 1600 pohon. Produktvitas kebun lada jika disetarakan dengan populasi sandar disajikan pada Tabel 4. Produktivitas lada di kedua kecamatan rata-rata pada periode 20162019 tidak berbeda nyata yaitu berkisar 230-260 $\mathrm{kg} / \mathrm{ha}$. Fluktuasi produksi tidak nyata di Kecamatan Abung Barat, namun di Kecamatan Abung Tengah terdapat perbedaan nyata produktivitas lada tahun 2017 dengan tahun 2018. Secara keseluruhan produktivitas kebun lada di kedua kecamatan ini sangat rendah dibandingkan dengan potensinya yang dapat mencapai 4 ton/ha (Evizal dan Prasmatiwi, 2019). Rendahnya daya hasil lada di Lampung Utara juga dilaporkan oleh Asnawi et al (2017) sebesar $285 \mathrm{~kg} / \mathrm{ha}$. 
Tabel 3. Dosis pemupukan lada

\begin{tabular}{llllll}
\hline Kecamatan & $\begin{array}{l}\text { Dosis pupuk } \\
(\mathrm{kg})\end{array}$ & $\begin{array}{l}\text { Urea } \\
(\% \text { petani })\end{array}$ & $\begin{array}{l}\text { Phonska } \\
(\% \text { petani })\end{array}$ & $\begin{array}{l}\mathrm{KCl} \\
(\% \text { petani })\end{array}$ & $\begin{array}{l}\text { NPK majemuk } \\
(\% \text { petani) }\end{array}$ \\
\hline Abung Barat & 0 & 50,8 & 57,1 & 68,3 & 57,1 \\
& 50 & 20,6 & 31,8 & 25,4 & 30,2 \\
& 100 & 28,6 & 9,5 & 6,3 & 11,1 \\
& 150 & 0 & 1,6 & 0 & 1,6 \\
Abung & 200 & 0 & 0 & 0 & 0 \\
Tengah & 0 & 43,3 & 63,3 & 83,3 & 60,0 \\
& 50 & 40 & 13,3 & 13,3 & 26,7 \\
& 100 & 13,3 & 16,7 & 3,3 & 10 \\
& 150 & 0 & 3,3 & 0 & 0 \\
& 200 & 3,3 & 3,3 & 0 & 3,3 \\
\hline
\end{tabular}

Tabel 4. Produktivitas kebun lada per ha pada SPH 1600 pohon

\begin{tabular}{lll}
\hline Tahun & Abung Barat & Abung Tengah \\
\hline 2016 & $219,14 \pm 60,78$ & $279,45 \pm 90,69$ \\
2017 & $170,69 \pm 60,73$ & $303,17 \pm 121,57$ \\
2018 & $219,54 \pm 66,37$ & $191,99 \pm 70,62$ \\
2019 & $314,30 \pm 79,32$ & $264,62 \pm 82,73$ \\
Rata-rata & $230,92 \pm 66,80$ & $259,81 \pm 91,40$ \\
\hline
\end{tabular}

Keterangan: Nilai tengah yang diikuti huruf yang sama tidak berbeda nyata pada uji BNJ 5\%

Produtivitas tanaman lada per pohon disajikan pada Gambar 2. Produktivitas tanaman lada di kedua kecamatan tidak berbeda nyata yaitu rata-rata 1,44 ons per pohon di Kecamatan Abung Barat dan 1,77 ons per pohon di Kecamatan Abung Tengah. Apabila dikembalikan pada populasi pohon per ha (Abung Barat 1308 pohon/ha, Abung Tengah 1567 pohon/ha) maka produktivitas kebun lada di Kecamatan Abung Barat sebesar $190 \mathrm{~kg} / \mathrm{ha}$ dan di Kecamatan Abung Tengah sebesar 277 $\mathrm{kg} / \mathrm{ha}$.

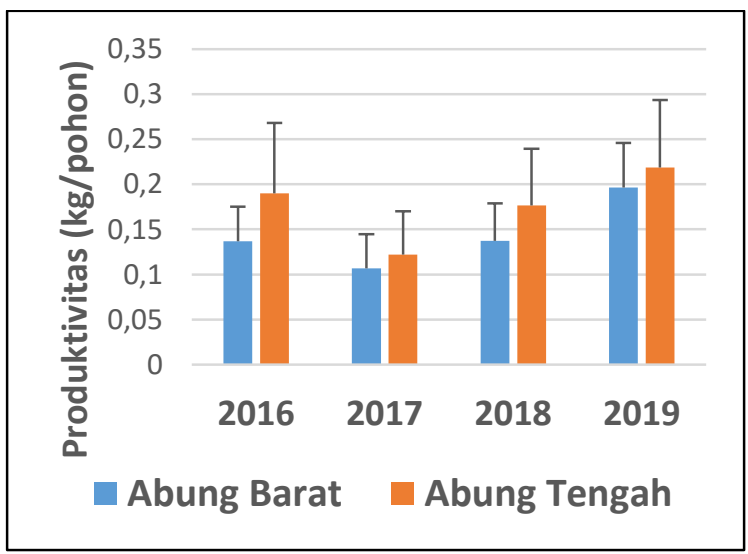

Gambar 2. Produktivitas lada per pohon

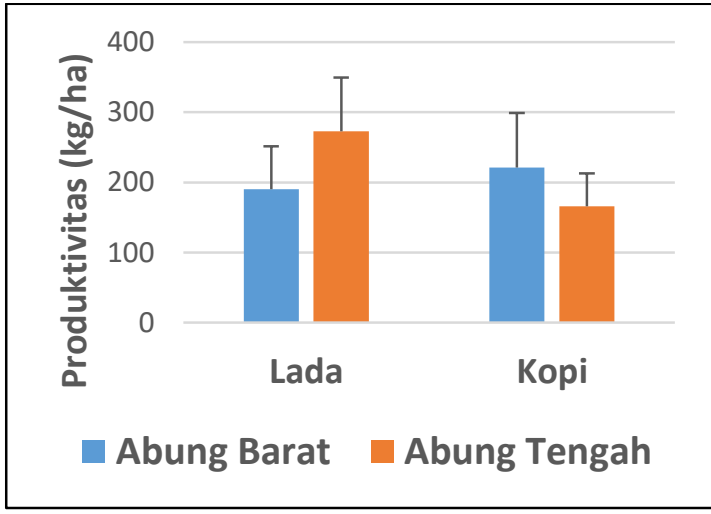

Gambar 3. Produktivitas per ha tumpangsari lada dan kopi

Secara keseluruhan produktivitas lada tumpangsari kopi disajikan pada Gambar 3 yang menunjukkan bahwa produktivitas lada dan kopi sistem tumpangsari di kedua kecamatan tidak berbeda nyata. Di Abung Barat produktivitas kopi hasil tumpangsari mencapai $221 \mathrm{~kg} / \mathrm{ha}$ sedangkan di Abung Tengah mencapai 166 $\mathrm{kg} / \mathrm{ha}$ yang diperoleh dengan populasi kopi masing-masing 313 pohon/ha dan 425 pohon per ha. Apabila dikonversikan kepada SPH kopi 2000 pohon per ha maka tingkat produktivitas masing-masing kecamatan mencapai 1,4 ton/ha 
dan 0,8 ton/ha yang menunjukkan tingkat produktivitas kopi yang cukup tinggi.

Produktivitas per pohon tanaman tumpangsari yaitu tanaman kopi dan jengkol disajikan pada Gambar 4 dan Gambar 5 yang menunjukkan bahwa produktivitas kopi per pohon di kedua kecamatan tidak berbeda nyata yaitu $0,66 \mathrm{~kg} /$ pohon untuk di Kecamatan Abung Barat dan 0,46 kg/pohon untuk Kecamatan Abung Tengah. Data ini juga menunjukkan tingkat produktivitas kopi tumpangsari lada yang cukup tinggi.

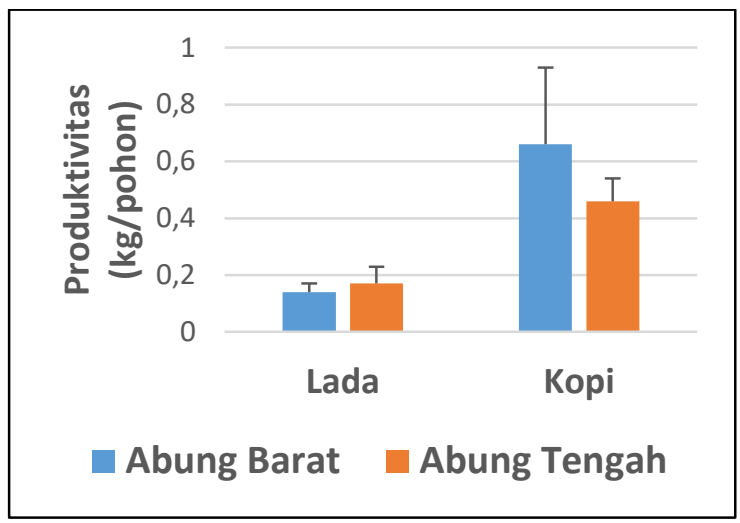

Gambar 4. Produktivitas per pohon tumpangsari lada dan kopi

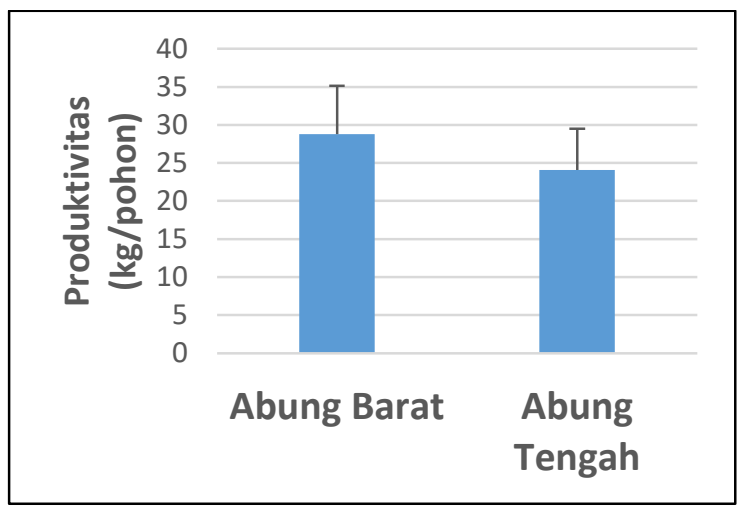

Gambar 5. Produktivitas jengkol per pohon tumpangsari lada-kopi

Selain itu sistem tumpangsari ini juga menghasilkan buah jengkol yaitu rata-rata 28 $\mathrm{kg} /$ pohon untuk di Kecamatan Abung Barat dan $24 \mathrm{~kg} /$ pohon untuk di Kecamatan Abung Tengah. Produktivitas buah jengkol sistem tumpangsari ini tidak berbeda nyata antara dua kecamatan. Petani Lampung Utara umum bertanam jengkol di kebun lada dan kopi dengan populasi sekitar 10 pohon per hektar sebagai salah satu sumber pendapatan yang penting. Pada saat penelitian ini dilakukan harga jengkol sebesar Rp 15.000 per kg.

\section{Masalah Usahatani Lada}

Persepsi petani tentang masalah dalam usahatani lada disajikan pada Tabel 5, yang menunjukkan banyaknya kendala dalam usahatani lada yang dapat menyebabkan menurunnya produksi lada dari wilayah ini karena menurunnya luas areal dan produktivitas tanaman lada. Kendala utama yang dirasakan oleh umumnya petani lada (80,2\% petani) adalah adanya serangan penyakit busuk pangkal lada, rendahnya harga lada, dan tingginya angka kematian pohon lada. Tingginya angka kematian tanaman lada juga terkait dengan serangan penyakit busuk pangkal batang dan adanya kemarau panjang.

Untuk mengatasi masalah ini petani menerapkan penyulaman lada setiap tahun. Praktik ini merupakan kearifan lokal dan etnoagronomi petani lada di Lampung khususnya di Lampung Utara. Praktik inilah yang antara lain mendukung keberlanjutan produksi lada di Lampung Utara. Sebanyak $89,9 \%$ petani menyatakan tidak ingin mengganti tanaman lada dengan tanaman lain. Alasannya karena bertanam lada sebagai tradisi yang sudah dilakukan secra turun temurun serta adanya harapan sukses berusahatani lada apabila harga tinggi dan musim buah lada yang baik yang dapat mewujudkan cita-cita petani seperti membangun rumah yang bagus dan berangkat ibadah haji.

Usahatani lada sangat sensitif terhadap penurunan harga dan penurunan produktivitas (Meliyana et al, 2013). Apabila daya saing lada rendah maka secara rasional petani dapat terdorong mengganti kebun lada menjadi pertanaman lainnya (Evizal dan Prasmatiwi, 2019). Penerapkan teknologi pemupukan dan polikultur secara benar perlu didorong mengingat capaian produktivitas lada masih jauh di bawah potensinya (Ardana et al., 2017). 
Tabel 5. Persepsi petani tentang masalah dalam usahatani lada

\begin{tabular}{clc}
\hline \multicolumn{1}{c}{ Persepsi } & \multicolumn{1}{c}{ Penyebab } & Jumlah petani (\%) \\
\hline Kendala usahatani lada & Penyakit busuk pangkal batang & 29,6 \\
& Harga lada rendah & 27,2 \\
& Kematian pohon lada & 23,4 \\
& Keamanan dari pencurian & 7,4 \\
& Penurunan hasil lada & 6,2 \\
& Serangan hama & 2,5 \\
& Kemarau panjang & 2,5 \\
& Penurunan kesuburan tanah & 1,2 \\
& Jumlah & 100 \\
Alasan tidak mengganti lada dengaan & Sesuai tradisi, keterampilan dan & 63,4 \\
tanaman lain & kearifan lokal & 25,8 \\
& Mengharap akan ada harga & \\
& tinggi & 10,8 \\
& Letak kebun jauh, sulit untuk & 100 \\
& tanaman semusim & \\
& Jumlah &
\end{tabular}

\section{KESIMPULAN}

Dari hasil penelitian ini dapat disimpulkan bahwa bahwa:

(1)Sebanyak 96\% petani menerapkan sistem perkebunan lada polikultur. Kebun lada polikultur memiliki populasi tanaman lada yang lebih rendah namun dengan adanya tanaman tumpangsari dapat menyebabkan efisiensi pemanfaatan lahan meningkat sampai $30 \%$.

(2)Kebun lada polikultur dikelola secara kurang intensif yang diindikasikan oleh rendahnya dosis pupuk dan tingginya angka kematian lada yang mencapai 7 $10 \%$ tanaman per tahun.

(3)Produktivitas sistem tumpangsari ini adalah lada (konversi SPH 1600 pohon/ha) mencapai $230-260 \mathrm{~kg} / \mathrm{ha}$ atau berdasar populasi faktual mencapai 190$277 \mathrm{~kg} / \mathrm{ha}$, produktivitas kopi 166-221 $\mathrm{kg} / \mathrm{ha}$, dan produktivitas jengkol 24-28 $\mathrm{kg} /$ pohon.

(4) Menurut persepsi petani kendala utama yang dirasakan oleh umumnya petani lada $(80,2 \%$ petani) adalah adanya serangan penyakit busuk pangkal batang lada, rendahnya harga lada, dan tingginya angka kematian pohon lada. Namun demikian umumnya petani $(88,9 \%$ petani) menyatakan tidak akan mengganti lada dengan tanaman lain.

\section{DAFTAR PUSTAKA}

Ardana, M. Syakir, E. Karmawati, dan Siswanto. 2017. Potensi Dampak Ekonomi Penerapan Teknologi Pemupukan dan Polikultur Lada di Kabupaten Purbalingga, Provinsi Jawa Tengah. Jurnal Littri, 23(2):112-122.

Asnawi, R., Zahara, dan Arief R.W. 2017 Pengaruh pengelolaan faktor internal usahatani terhadap produktivitas lada di Propinsi Lampung. Jurnal Littri. 23(1): 110.

BPS Propinsi Lampung. 2018. Lampung Dalam Angka 2018. Bandar Lampung.

Evizal. R. 2000. Pola budidaya lada sistem panjatan hidup di Propinsi Lampung. Jurnal Agrotropika, 5(1): 14-19.

Evizal, R. and Prasmatiwi, F.E. 2005. Economic potentials of legume crops in plantation management. In Arifin, B., Ismono, $\mathrm{H}$. and Utomo, M. (Eds). The Future Use of Legume Nodulating Bacteria (LNB) in Indonesia Technical and Economic Perspectives. Universitas Lampung, Bandar Lampung. pp 62-72. 
Evizal, R. 2013a. Status fitofarmaka dan perkembangan agroteknologi cabe jawa. Jurnal Agrotropika, 18(1):34-40

Evizal, R. 2013b. Tanaman Rempah dan Fitofarmaka. Lembaga Penelitian Universitas Lampung. Bandar Lampung.

Evizal, R., Sugiatno, Prasmatiwi, E.P., Nurmayasari, I. 2016. Shade tree species diversity and coffee productivity in Sumberjaya, West Lampung, Indonesia. Biodiversitas, Journal of Biological Diversity, 7(1): 234-240.

Evizal, R., Prasmatiwi, F.E., Syam, T., Pujisiswanto, H. dan Sutrisna R. 2017. Sistem integrasi ternak ruminansia dan tanaman di perkebunan kopi semiorganik. Prosiding Seminar Nasional Dan Rapat Tahunan Dekan Bidang Ilmu Pertanian BKS-PTN Wilayah Barat. pp 1033-1040.

Evizal, R. dan Prasmatiwi, F.E. 2019. Agroteknologi Perkebunan Lada Lampung. Dalam Sudarsono, H. dan Erwanto (Eds). Revitalisasi Lada Lampung Sebagai Komoditas Warisan. Aura, Bandar Lampung. pp 113-36

Evizal, R. dan Prasmatiwi, F.E. 2020. Agroteknologi Kopi Grafting untuk Peningkatan Produksi. Jurnal Agrotek Tropika, 8(3): 423-434.

Evizal, R., Prasmatiwi, F.E., Widagdo, dan Novpriansyah, H. 2020. Etno-agronomi budidaya kopi yang toleran variabilitas curah hujan. Jurnal Agro Industri Perkebunan, 8(1): 51-61.

Karmawati, E., Ardana, I K., Siswanto, and Soetopo, D. 2020. Factors effecting pepper production and quality in several production center. IOP Conf. Ser.: Earth and Environ. Sci. 418012051.

Krishnamurthy, K. S., Kandiannan, K., Sibin, C., Chempakam, B. and Ankegowda, S.J.
2011. Trend in climate and productivity and relationship between climatic variables and productivity in black pepper (Piper nigrum L.). Indian J. Agron., 81(8): 729-733.

Krishnamurthy, K.S., Ankegowda, S.J., Srinivasan, V. and Hamza, S. 2013. Influence of carbohydrates, mineral nutrients and plant hormones in alternate bearing of black pepper (Piper nigrum L.). Am. J. of Plant Sci. 4: 1960-1967.

Meliyana, R., W. A. Zakaria, I. Nurmayasari. 2013. Daya saing lada hitam di Kecamatan Abung Tinggi Kabupaten Lampung Utara. Jurnal Ilmu-ilmu Agribisnis, 1(4): 271-277.

Munawaroh, S., Nurmauli, N., Sugiatno, dan Evizal, R. 2020. Pertumbuhan bibit lada (Piper nigrum L.) pada media pembibitan dan waktu aplikasi pupuk NPK. Jurnal Galung Tropika, 9(2): 105-114.

Rusiva, R. and Suherman. 2019. The role of organic fertilizer and plant material in the growth of pepper seeds for sustainable agriculture. IOP Conf. Series: Earth and Environmental Science 383 (2019) 012041 IOP Publishing doi: 10.1088/1755-1315/383/1/012041.

Sulok, K.M.T., Ahmed, O.H., Khhew, C.Y. and Zehnder, J.A.M. 2018. Introducing natural farming in black pepper (Piper nigrum L.) cultivation. Hindawi Int. J. of Agron. DOI 10.1155/2018/9312537.

Yudiyanto, Rizali, A., Munif, A., Setiadi, D. and Qayim, I. 2014. Environmental factors affecting productivity of two Indonesian varieties of black pepper (Piper nigrum L.). Agrivita, 36(3): 278-284. 